\title{
ON CRITERIA OF LITERAL SIGNIFICANCE
}

ALICE AMBROSE

Smith College

Logical empiricism has been something of an intellectual crusade, a crusade with the joint mission of eliminating metaphysics from intelligible discourse and of unifying the sciences through the medium of a common language. The elimination of metaphysics was the primary motive force behind the positive program of unifying the sciences. Both programs stem from a thesis about the meaningfulness of factual statements, a thesis which can be stated roughly as follows: all intelligible talk about the world consists of statements amenable to testing by the methods of the natural sciences. The effect of this thesis on theology and metaphysics immediately placed logical empiricists at the center of a long-standing conflict between religion and science, and within philosophy itself, between empiricism and rationalism. It will be remembered that Plato held that the sphere of knowledge was the supersensible, the sphere of unchanging forms, and that only opinion was possible of the world of sense-experience, the world investigated by the sciences. Centuries later, with Kant, we witness a fundamental reversal: this world is the sphere of knowledge, and the supersensible is the sphere of opinios, Kant, it was thought made science completely independent of religion, and brought rationalism and empiricism into a fruitful unity. The pronouncements of supersensible philosophies were declared beyond the limits of the knowable, and a firm foundation for the natural and mathematical sciences was laid down.

At this point in history, and up to the time of logical 
positivism, it might appear that a reasonable balance between the two rival philosophical traditions had been reached -that sense-experience and a priori reasoning as sources of knowledge had both been given their due and their pretensions radically limited. Logical positivists, however, look back on this point in history as a way station at which Kant should not have stopped. Kant eliminated methaphysics from science but not from intelligible discourse- which left open the possibility of its return to its former status. The Vienna Circle of positivists completed the eviction by eliminating it from discourse which counts as literally meaningful. "Our charge against the metaphysician," says Ayer, "is not that he attempts to employ the understanding in a field where it cannot possibly venture, but that he produces sentences which fail to conform to the conditions under which alone a sentence can be literally significant." The fruitlessness of metaphysical controversy suggests a difficulty more drastic than that created by the inaccessibility of a subject matter to human investigation. So the logical empiricist turns his attention away from the supposed real. ities to which theology and metaphysics refer and investigates their language. His conclusion is that however significant their language may be emotionally it fails to do what it purports to do, express something true or false. Taken literally, it is meaningless. Literally significant language coincides with what, in a wide sense, may be called the language of science. In accordance with this thesis the program of philosophy can no longer be conceived in a traditional tway. For one thing, it can no longer be its task to bring science (in the narrower sense) and metaphysical theology into a unity. There exists no gap between them to bridge, for the discourse of science and discourse beyond science are not two separate linguistic spheres on the same footing of intelligibility. Between intelligible language and the literally meaningless no unity can be effected. The only

1 Language, Truth and Logic, Second edition, p. 35. 
unity it is possible to effect, and which philosophy is competent to effect, is a unity of the various areas of scientific discourse.

The two aims of logical empiricism, one the elimination of metaphysics and the other the unification of the sciences via a single language in which everything intelligible can be expressed, are intimately connected and have a number of interesting implications both for philosophy and for the foundations of science. For one thing, to eliminate metaphysics required showing that that area of traditional philosophy consisted of pseudo-problems, and it required specifying the nature of philosophy as thus curtailed and the method by which its problems could be pursued. For another thing, the elimination of metaphysics meant ridding the language of science of a kind of infection. And this required possessing a positive idea of what ideally the language of science would be like. More than this, to justify such an iconoclastic attack, it had to be shown specifically how a basic scientific language on which all intelligible discourse rested could be constructed. Let us turn now to the linguistic distinctions which prompted the negative thesis back of their positive program.

Compare such statements as "There are specks of dust on the window", "There are no odd perfect numbers", and "The Absolute is one". About the first two one can ask whether what they express is true, or false; but about the last there exists the prior question whether it expresses anything at all. The status of this typical metaphysical statement is peculiar. Though it appears to assert something to be a fact, it is impossible to describe, let alone carry out, either a verification or a falsification of it. This is the situation not only of this statement which supposedly refers to a supersensible object, but of such a statement as Berkeley's: "Physical objects exist only when perceived." How describe a means of establishing that physical objects do not exist unperceived? or a means of disestablishing it? Philosophy has been described as the catch-all of insoluble 
problems. But it comes seriously in question whether they are real problems if the proposed solutions cannot be checked. Can a statement be held to be meaningful if it can neither be verified nor falsified? The positivists' answer was No. And it at once became incumbent on them to formulate a criterion of meaningfulness.

Wittgenstein, whose influence on the Vienna Circle was very great, gave a general characterization of meaning which provided a distinction between two classes of statement to which any criterion of significance should guarantee meaning: a priori statements and empirical statements. His characterization was that the meaning of a statement is its method of verification. ${ }^{2}$ Empirical statements such as "There are specks of dust on the window" express something testable by observation. $A$ priori statements such as "There are no odd perfect numbers" or " $p \mathrm{v} \sim p$ " are such as can have only a priori demonstrations. No matter of fact can have any bearing on their truth or falsity. To these radically different methods for establishing them correspond, according to positivists, a difference in kind of meaning. Their difference is sufficiently important to remark on. Of logical propositions Wittgenstein said in the Tractatus (6.1222) that they "can no more be empirically established than they can be empirically refuted. Not only must a proposition of logic be incapable of being contradicted by experience, but it must also be incapable of being established by any such." This description he coupled with the assertion that they "say nothing", by which he meant simply that they afford no information about any matter of fact. As Ayer puts it, they are "devoid of factual content". In opposition to Kant's classification of some statements as both synthetic, i.e., about the world, and a priori - capable of establishment by reason alone, the positivist holds that no statement to which observation is irrelevant can make any factual assertion. Their truth, as Ayer says, "follows simply from the definition

2 From lecture notes taken by Alice Ambrose, 1932-33.

3. Op. cit., p. 79. 
of the terms contained in [them]".4 "It is the characteristic mark of propositions of logic", said Wittgenstein in the Tractatus (6.113), "that one can perceive in the symbol alone that they are true". Of the other class of meaningful statements, those expressing non-logical, or empirical propositions, he noted "the important fact" (6.113) that their truth or falsity could not be recognized from the symbolism alone. That it is possible to verify or falsify these by senseobservation is a way of saying that they differ radically in meaning from a priori statements. Positivists have embodied this feature of empirical statements in a general criterion for their meaningfulness. The criterion, in its original formulation, was: A non-a priori statement is meaningful if and only if it can be verified or falsified in sense-experience. Some form of this so-called verifiability criterion is perhaps the best-known feature of logical empiricism.

Now it is interesting to note that metaphysical statements appear to straddle both classes of meaningful statements. They seem to assert something factual, and at the same time, demonstrations adduced for them make no use of observation or experiment. Bradley's claim about the Absolute and Berkeley's about physical objects are reached by a chain of reasoning in which no observational evidence whatever is appealed to. It is the positivist's thesis that the appearance of making a factual claim is spurious, and not because we have no practical means of verifying or falsifying them, but because they are, as he says, "in principle" untestable: We cannot describe what it would be like to discover that they are true or that they are false.

The question soon arose, however, whether all non-metaphysical statements could meet this verifiability criterion. In order not to eliminate as meaningless statements whose factual significance is undeniable, a reformulation of it was seen to be necessary. Consider "All crows are black". Being universal, it cannot be conclusively established, for the in.

- Op. cit., p. 82 . 
finity of confirmatory observations required cannot, even in theory, be made. In consequence the criterion was weaken. ed to read: A non-a priori statement is meaningful if it is capable in principle of being confirmed, that is, if evidence capable of rendering it probable can be described. Metaphy. sical statements still do not qualify as meaningful by this weakened principle of verifiability. To see this, consider the philosophical claim which seems so natural a consequence of the distinction we make between sensible appearances of a thing and the thing of which they are appearances, namely, "Underlying the knowable qualities apprehended by our senses there is an unknowable something in which the qualities inhere". Substratum is not experienceable directly nor, as it turns out, is there an indirect means of establishing its existence. We cannot imagine conclusively verifying that is exists, as that would require an observ. ation of substratum itself, nor can its existence be rendered probable. For what can be rendered probable by indirect evidence we can imagine being known to exist independently of that evidence - by direct observation. Accordingly the positivists conclude that this statement is nonsense.

Again, consider the statement "There is a god", which theists, atheists, and agnostics are agreed is either true or false. Far from supporting the religiously minded who hope to give theology and science each its own sphere of discourse, the positivist rejects the theist's statement as devoid of literal sense. But the atheist's and agnostic's statements fare no better: they too are rejected as lacking intelligibility. It is worthwhile seeing precisely which statements it is that the positivist thus condemns. The statement "There is a god" we could easily conceive ourselves as verifying if by "god" is meant a titanic figure such as is portrayed by Michelangelo. But metaphysical theologians have not concerned themselves with this use of the word "god". Consider Plotinus' statement that about the Unity which is presupposed by experienced diversity in the world we can only say what it is not, never what it is. One could not describe any 
sense-evidence for the existence of such an entity, even in theory. No conceivable observation or experiment could render probable or improbable the existence of the "Ineffable Unity", the One which lies beyond description. Or consider the notion of an absolutely perfect being, than which a greater cannot be conceived. Granting we know what it is like for a being to have perfections in their limiting degree, which is doubtful, do we know what it is like for a transcendent being to have these? Suppose it is argued that the presence of design in the world is evidence for a trascendent god. Circunmstantial evidence is always such that the thing to which it points can be known to exist independently of that evidence. Here however, we are logic ally confined to the supposed circumstantial evidence, which means that the statement "There is a designer" reduces to the statement "There is design" - it can mean nothing in addition if no conceivable evidence beyond the presence of design exists. And this means that what has been put forward as evidence for something is not evidence, but a kind of deception. In general it can reasonably be held that we do not know what it is like for a statement to be rendered probable, or improbable, unless we know what it is like for the probability limits 1 and 0 to be reached, that is, what it would be like for it to be conclusively established, or conclusively disestablished.

This point bears on the tightened formulation of the criterion of meaningfulness in terms of partial as against conclusive evidence. If the possibility of describing the evidence rendering a statement probable rests on the possibility of describing the evidence which would verify it conclusively, then any universal statement which no finite number of observations could conclusively establish will again be ruled out as meaningless. It is an anomaly that the existential statement which is its negative will be meaningful, since there is no theoretical obstacle to its verification. Positivists have, over a period of some twenty years, attempted to formu. late an unobjectionable criterion of literal significance -a 
criterion which will not rule out statements which are meaningful or let in statements which are meaningless. How difficult of achievement this is can be inferred from the num. ber of attempts made, and positivists have been fully aware of the difficulties. In a paper of $1950^{5}$ Prof. C. G. Hempel, sums up what the difficulties are. Surprisingly, the requirement of conclusive verifiability turns out not only be too drastic - by ruling out certain universal statements which are obviously meaningful-, but to be not drastic enough. It allows meaningless statements to count as meaningful. For example, suppose a statement $\mathrm{S}$ does meet the requirement, then since $\mathrm{S}$ implies the disjunction $\mathrm{S} v \mathrm{~N}$, where $\mathrm{N}$ might be "The Absolute is perfect", $\mathrm{S} v \mathrm{~N}$ would count as meaningful.

The difficulty presented the principle of conclusive verifiability by universal statements requiring an infinite number of confirmatory observations Prof. Karl Popper tried to circumvent ${ }^{t}$ by a new criterion, namely: that a statement counts as meaningful if it is in theory falsifiable. Universal statements which are not capable of being verified can in principle be falsified. But the obvious difficulty in this criterion is that it would rule out as meaningless an existential statement such as "Unicorns exist", since no finite set of observations would falsify it. And the negation of this meaningless statement would on this criterion be meaning. ful. Further, if a statement $\mathrm{S}$ satisfied this criterion then so would any conjunction $\mathrm{S} \cdot \mathrm{N}$, since $\sim \mathrm{S}$ implies $\sim(\mathrm{S} \cdot \mathrm{N})$. Thus "S and the Absolute is perfect" would be meaningful. It is not possible to escape the difficulties presented by universal and existential statements by applying one criterion of meaningfulness to the one sort and the other criterion to the other sort, for then no criterion remains which covers statements involving both universal and existential

s "The Empiricist Criterion of Meaning", Retue Internationale de Philoso. phie, Vol. 4.

- Logik der Forschung, 1935. 
quantifiers, such as "For any substance there exists some solvent".

To circumvent these difficulties, Ayer formulated a criterion is that would rule out as meaningless an existential firmability and partial disconfirmability, namely that a statement $\mathbf{S}$ count as meaningful if $\mathrm{S}$ in conjunction with suitable subsidiary hypothesis yield observation statements not derivable from the subsidiary hypothesis alone. Thus if $\mathrm{S}$ is the statement "Light is wavelike", S taken together with the hypothesis "If light is wavelike then a ray will spread after entering a narrow aperture", will yieid the observation statement about light spread. And thereby $\mathrm{S}$ is guaranteed a meaning. Unfortunately, if $\mathrm{S}$ were "The $\mathrm{Ab}$. solute is perfect", and if S were conjoined with any hypothetical proposition of which it was the antecedent, $\mathbf{S}$ would by the same token be meaningful. It is not sufficient that the subsidiary hypothesis itself be required to be independently testable in the sense specified by the criterion. For this would allow the conjunction $\mathrm{S} \cdot \mathrm{N}$ to be meaningful, where $\mathrm{S}$ satisfies the criterion but $\mathrm{N}$ does not, since we can choose the subsidiary hypothesis $\mathrm{S} \cdot \mathrm{N} \cdot \supset \cdot q$, where $q$ is a true observation statement, to combine with $\mathrm{S} \cdot \mathrm{N}$.

The consequence of these unsuccessful attempts to free the criterion of meaningfulness from the difficulties cited above was to give up trying to specify the meaningfulness of a given statement in terms of its relations to observation statements. For if $\mathrm{S}$ and $\mathrm{N}$ are statements conforming to the rules of a natural language, then the criterion and its modifications will allow literal import to certain truth-function combinations of $\mathbf{S}$ and $\mathrm{N}$. This situation could not occur in a language whose vocabulary precluded the formation of statements of the kind $\mathrm{N}$ which the criterion was intented to exclude. Accordingly logical positivists took a different approach to specifying literal significance, suggested by the possibility of constructing an artificial language having a

; See Language, Truth and Logic, pp. 11.12. 
metaphysics-free terminology. Understanding by the characterization "empiricist language" such an artificial language, a new criterion of literal significance can be formulated: A non-a priori statement has cognitive import if it can be translated into a statement formulable in an empiricist lan. guage. With this conception of cognitive import, which according to Hempel underlay some of the quite early work of Carnap, the positive program of logical empiricists, and its connection with their negative program, comes to the fore. To this I now turn. The desideratum is: to construct a language into which all statements of the natural language which are amenable to test by the methods of science, and none others, may be translated. This program has the negative aim of keeping metaphysical terminology out of the scientist's workshop language and pseudo statements out of non-metaphysical philosophy; but it comprehends something further: Within science there is need for clarification of its concepts, and also for some structures on its language so as to eliminate laxness of usage. The philosopher's function vis à vis sciense is thus both explicative and correcti. ve he can provide a dictionary in the manner of Austin, and he can incorporate into this dictionary analyses of usage which correspond to, but are more precise than, familiar usage. Philosophy, as Carnap says, becomes analysis of language. The only thing left to it is the application of a me. thod: the method of logical analysis. Wittgenstein had said in the Tractatus (4.112) "The aim of philosophy is the logical clarification of thoughts. Philosophy is not a doctrine but an activity... The result of philosophy is not "philo. sophical propositions', but making propositions clear".

Logical empiricists have addressed themselves to a painstaking construction of an empiricist language. I shall turn now to a brief survey of this project and its problems. The syntax of such a language is just the rules of sentence-formation contained in some such logical system as Principia Mathematica. The crucial matter is its non-logical vocabu. lary, whose combinations these formation rules govern. In 
order not to have to embark at once on distinct positivist accounts of this part of the language, let us characterize it for the moment as consisting of observation terms. With this limitation of vocabulary, certain key terms of metaphysics will be lacking and hence the possibility of forming such sentences as "The Absolute is perfect" will not exist. Difficulties with various versions of the verifiability principle which arose from the possibility of constructing sentences of the form $\mathrm{S} v \mathrm{~N}$ and $\mathrm{S} \cdot \mathrm{N}$ will be avoided. And since "all" and "some" figure in the empiricist language, there will be no special difficulties, such as resulted from applying the verifiability, or falsifiability, criterion. In particular, if $\mathrm{S}$ is cognitively meaningful, so is $\sim \mathrm{S}$. In passing I might make one critical comment on the language described here. This is that it is not clear how it prevents the formation of such a sentence as "physical objects exist only when perceived".

Most of the difficulties which inhere in the translatability criterion of meaningfulness, framed by reference to an empiricist language, derive from the specifications of the observation terms. Each of the two ways of specifying these terms has led to the criticism that positivists thereby com. mitted themselves to metaphysical positions. Later positivists have made observation terms denote observable characteristics of physical objects, so that the basic language is a "thing-language", whereas in its beginnings Schlick, Carnap before "Testability and Meaning" appeared, Neurath, and Ayer apparently made the observation terms designate "the given", i.e., items in the scientist's immediate experience. The basic language is on this account a "phenomenalistic" language. Hempel refers to these vocabularies as alternatives, and comments on the difficulties presented by the construction of a phenomenalistic language. It is clear what the main difficulty is, but it arises whichever language is chosen as the language into which all intelligible language is to be translated. The difficulty is that of connecting inferentially the statements recording the scientist's experience 
with thing-statements - statements whose terms designate physical objects or events. Recall that the positive program of the empiricist is to show that all fact-claiming statements that are intelligible are expressible in a single language, which means that ultimately all states of affairs are of one kind, and all objects are of one kind. Carnap stated this program quite explicitly in The Unity of Science, fully recognizing that on the face of it statements about social groups, other minds, physical objects, and the data of our own minds do not appear to be intertranslatable. That is, it does not appear that all states of affairs and all objects are of the same kind, that statements of sociology, psychology, biology, and physics reduce to statements of one basic empirical sort.

Suppose now that the language chosen as the basic one to which these can in some sense be reduced is one whose observation terms stand for observable characteristics of physical objects. In order to secure that this language be "intersubjective", such scientists can check each other's evidential statements, it was mantained that all singular statements attributing sense qualities to physical objects can be interpreted as expressing " a quantitatively determined property of a definite position at a definitive time". The thesis that every statement of perceived fact can be expressed as a statement about physical conditions is the thesis of "physicalism". Positivists claimed it to hold whether the sentences of the basic empiricist language are taken to describe physical states or sensations. Whichever alternative is taken, the problem is the same: to specify the connection between statements recording the scientist's senseexperiences and thing-statements. But the form of the problems varies according as the observation terms designate simple qualities of sense and feeling, or things. If things, then the question is how statements such as "I see a crisscross of lines in the spectroscope" translate into statements

" R. Carnap, The Unity of Science, p. 52. Italics mine. 
about bodily or other physical states; and if sensory data, then the question is how thing-statements reduce to statements about them. Curiously, the one choice of basic lan. guage seems but another form of philosophical materialism, and the other choice seems to land the positivist in solipsism. That logical empiricists find themselves called upon to extricate themselves from the charge of being committed to an unverifiable philosophical position is of course ironical. And more than that, it is a charge which their program compels them to try to refute. At the same time they were beset by other difficulties, what one might call workshop difficulties encountered in carrying out their positive program.

Before considering the tu quoque charge that behind a show of science they are metaphysicians it is worthwhile detailing the difficulties they met in constructing a scien. tific language all of whose non-logical primitive terms are observation terms - leaving open for the moment the ques. tion as to what these observation terms designate. For such a language to serve any purpose it is required that scientific statements of the natural language be translatable into statements involving only such terms. And this requires that every word have its meaning explicated by reference to words occurring in observation sentences. A world will count as significant only if sentences in which it occurs are reducible to these basic sentences. Were words always so tractable as to be capable of elimination from a sentence by simply replacing them by their definiens, the reduction program could go forward apace; that is, if every word were replaceable by its definiens the way the word "square" is replaceable by "quadrilateral having equal sides and angles". But not all terms can be made to give way, without loss, to observation terms in this simple way. Three classes of terms presented their program with difficulties of one kind or another: dispositional terms, such as "magnetic", metrical terms, such as "length", and terms for theoretical constructs, such as "electron". Consider the first type of 
terms, standing for dispositions to display certain reactions under certain conditions. Their meaning is provided by a contextual definition, that is, by the explication of " $x$ has Q", which takes the form of an "if. . .then..." statement involving the dispositional term Q. For example, " $x$ is mag. netic" equals "if a small iron object is close to $x$ it will move towards $x$ ". The objection to this type of explication is that with the clear-cut interpretation of "if... then..." as material implication, one could infer that $x$ is magnetic when no iron object is in the vicinity of $x$; no empirical test would be required to show that $x$ had this property. If one were to reframe the contextual definition in terms of a subjunctive conditional phrase, e.g., " $x$ is magnetic" equals "if an iron object were close to $x$ then it would move towards $x$ ", the difficulty is merely shifted: How is the subjunctive conditional to be analyzed? Carnap tried to circum. vent these difficulties by introducing dispositional terms, not by a definition, but by a series of what he called reduction sentences. These have the form: $\mathrm{P}_{1} \mathrm{x} \supset\left(\mathrm{Qx} \equiv \mathrm{P}_{2} \mathrm{x}\right)$; where $Q$ is the term being introduced and $P_{1}$ and $P_{2}$ name properties $x$ has. For example: If an iron object is close to $x$, then $x$ is magnetic if and only if that object moves towards $x$. If no iron object is near $x$, then the whole state. ment will be true, but from it we cannot infer that $x$ is magnetic, as we could in the case of the first attempt at explication. This new formulation has its own difficulties, however. As Hempel sums them up, it does not give a com. plete explication of " $x$ is magnetic", but states only what it means when the test conditions are satisfied, not what it means when no iron object is near $x$. Hence terms introduced by reduction sentences cannot be eliminated in favor of primitive terms. If one tries to determine their meaning completely by giving a series of reduction sentences, two difficulties immediately crop up. One difficulty is that this series cannot be specified, since one cannot include in it the unforeseeable ways in which, e.g., magnetism makes its presence known, nor can one allow the meaning of a term 
to change with each additional discovery. The oher difficulty is that to take a pair of reduction sentences as giving even a partial explication has the implication that what is expressed by such a pair will imply an empirical law, and that the reduction sentences cannot be used to explicate a meaning unless there is evidence for the law. To use Hempel's example, suppose in addition to the above mentioned explication of " $x$ is magnetic" we had "if $x$ moves through a closed wire loop, $x$ is magnetic if and only if an electric current flows through the loop". The two explications taken together imply the law that any $x$ which is close to an iron object and moves through a loop will generate a current in the loop if and only if $x$ attracts the iron body.

The empiricist thesis that all terms are reducible to observation terms faces another sort of difficulty in connection with metrical terms, e.g., "length", "mass", etc. The properties these terms denote have a non-denumerably infinite number of values, and it is obviously impossible to establish for each value an observational criterion. "length $=r \mathrm{~cm}$." cannot be explicated either by a definition or by a series of reduction sentences naming the observation criterion to be satisfied by every value of $r$. The situation is even worse for the explication of abstract terms designating theoretical constructs such as "electron". The terms denoting these concepts are often not introduced into scientific theories either by definitions or by reduction sentences, as Hempel notes, or by any piecemeal process. These terms appearing in the expression of a scientific theory have only an indirect connection with observational data, and if the connection is made via either dispositional terms or reduction sentences, the difficulties above cited obtain. Some positivists, e.g., Hempel, are thus ready to admit that the thesis that theoretical statement can be translated into classes of evidence statements is untenable". "In fact positivists have themselves raised objections as quickly as their critics, and if unable

\footnotetext{
9 "A Note on Semantic Realism", The Philosophy of Science, vol. 17.
} 
to meet them have in some cases admitted it. They appear to have admitted the unsuccessfulness of attempts to specify the criterion for the meaningfulness of a statement by reference either to the observation statements which support or disconfirm it or by reference to a language into which it trans. lates without remainder.

How is it now with their attempt to eliminate metaphysics? In particular, is their own position uncontaminated by metaphysics? Their critics have charged that they are commited to materialism. Positivists can reply that if materialism is equivalent to physicalism, then they have no objection to it. Unlike the bourgeois gentilhomme who was surprised to learn that he had been speaking prose all his life, logical empiricists have always known their language was materialistic. Nevertheless, physicalism is claimed to be distinct from philosophical materialism; for one thing, the latter implies the meaningfulness of the statement that a God exists, whereas such a statement cannot be formed from the vocabulary of an empiricist language. Is it, however, so easy to escape identification with philosophical materialism? Is not the thesis that every empirical statement is expressible in a single intersubjective language a cover for the materialistic thesis that all facts are physical? Does not the positivist merely transfer the issue of materialism versus idealism or dualism to a linguistic level? Carnap calls attention to two modes to speech: the "material mode", in which objects and states of affairs are des. cribed as the referents of propositions, and the "formal mode", in which statements and the words from which these are compounded, are described. For example, to say a language is universal is to say in the formal mode of speech that every sentence is translatable into it; in the material mode, that it can describe every state of affairs. The thesis that the physical language is a universal language is the thesis that statements of each of the sciences, including biology, psychology, sociology, are translatable into it; and further, that all states of affairs, all qualities, and all objects 
are of one kind, namely, quantitatively determinable. In particular, statements recording the sense-evidence by which the scientist confirms or refutes a statement in question are expressible in physical terms. In his early brochure The Unity of Science Carnap held that such statements were deducible from statements about bodily states, "Red is being seen by $\mathrm{S}$ now" entails and is entailed by "The body $\mathrm{S}$ is seeing red now". But this surprising claim loses its surprise when it comes on the heels of the following proposal: "Let us denote by 'seeing red' that state of the human body characterized by the fact that certain physical reactions appear in answer to certain physical stimuli". ${ }^{10}$ This surely is a proposal that "materialism" in an important sense, be accepted - or as they term it, "logical behaviorism". But this is materialism by fiat. There is no argument given to show that a statement about a scientist's experience is equivalent to, or even entails a statement about a bodily state.

The appeal of a thing-language into which statements about experiences translate is obvious: only if the latter are taken to be about bodily conditions can they be tested intersubjectively. But if we recall the early formulations of the verifiability principle, which so explicitly calls attention to the way in which the scientific thing-statements are tested, and which explicitly places the source of knowledge in senseexperience, it is natural to make the vocabulary of the basic empiricist language denote data of the mind, the given contents of consciousness. This is to make a phenomenalist, egocentric language the basic or "protocol" language. With this different start the problem of describing the relation between experiential statements and thing-statements is accordingly altered. The question now is: How do thing-statements connect with the protocol language of each scientist and with the non-overlapping languages of a number of scientists? And the question the critics of empiricism ask now changes to: How can it escape commitment to solipsism?

10 P. 87. 
First of all, it is clear that no statement about one's immediate experience entails a thing-statement, else the possibility of recording an hallucinatory experience would be precluded. Second, if the words in $\mathrm{S}_{1}$ 's protocol language, e.g., "thirst", named sensations of $S_{1}$, whereas the same word of $\mathrm{S}_{2}$ referred to sensations of $\mathrm{S}_{2}$, then each protocol language would be used only solipsistically. No protocol statement of $S_{1}$ 's language could express the fact $S_{z}$ was thirsty. In fact this statement would be unverifiable by $\mathrm{S}_{1}$ if "thrist of $\mathrm{S}_{z}$ " meant a private sensation of $\mathrm{S}_{z}$. And if the protocol and physical languages recorded different facts then there is no explaining how physical descriptions are verified. I should make clear that I am here expounding what Carnap conceived as a difficulty from which a way out had to be found. The philosophical muddle in this account is itself a fit subject for investigation; but here I am only interested in expounding what I gather is Carnap's way out. He held that if we restricted ourselves to the formal mode of speech these difficulties would disappear. I am uncertain how he expected this to be effected, but possibly he expected these difficulties not to arise if one succeeded in finding a linguistic bridge between sentences of the physical and protocol languages. What this bridge is has been most clearly stated by Ayer; and Carnap up to the time of "Testability and Meaning" can be supossed to have agreed. The connection is effected by a translation of statements about material things into a series of implicative statements about sensecontents. " $x$ is a table" means "if certain specifiable conditions are fulfilled, then a sense-experience will occur". This is the linguistic counterpart of the phenomenalist position expressed in the material mode, that material things are constructs of actual and possible sense-contents.

There are two crucial criticisms of this account, one that phenomenalism is simply another philosophical position, from which it is difficult to scape eventual idealism. How far the positivists went in the direction of idealism can be 
measured by the fact that Neurath and Carnap, who were opposed by Schlick, put forward a coherence theory of truth concerning things-statements. It was held that these statements cannot be compared with objects but only with each other, so that their truth is to be determined by their agreement with the totality of accepted statements. On the other hand if, as Schlick held, all thing-statements are to be tested by reference to immediate experience, since no finite number of statements recording these experiences will entail a thing-statement, no thing-statement can, in principle, be conclusively verified. The question then arises whether basic statements can be held to render any statement probable if one cannot describe what it would be like for it to be established, or for its probability to be 1 . To put the question differently, does one know what it is like for a thing-statement to be true if its reduction to "if...then..." statements is an infinite process? In fact do we know what a statement means if its analysis is an infinite conjuction, or what it is for a statement to reduce to or translate into such a conjunction? But underlying all these questions is the question posed by solipsism: Is there any bridge between the indubitable statements of one's private experience and the dubitable statements about things? It is not clear how linguistic phenomenalism escapes solipsism with any more success than phenomenalism expressed in the material mode of speech.

The other crucial criticism is that not even a partial reduction of a thing-statement to a series of implicative statements about sense-contents has ever been effected. It is clear that the hypothesis of these "if...then..." statements cannot refer to human bodies, if one is "reducing" a statement about a material thing: one cannot say, "if I were standing here, I should be seeing an elliptical datum". Ayer admits that we are, however, "obliged to mention material things when we wish to describe certain sense-contents, because the poverty of our language is such that we have no other verbal means of explaining what their properties 
are." 11 One is given no hint as to how this poverty of lan. guage might be made good. With a phenomenalist language as basic apparently the program of providing a language common to all the sciences fails.

What the purposes to be accomplished by such a language are have never been made entirely clear, except in one respect. One can suppose that a language with precise formation rules into which such part of our familiar natural language as is exact enough will translate is aimed at pruning from ordinary language vague and lax usages. One might even suppose that positivists wish to change ordinary language into scientific language - to reform it so that it is regular enough to conform to exact rules. One is reminded of the comparable thing of which Aristotle complained when he left the Academy - that they wished to change philosophy into mathematics. Whether logical empiricists intended a general reform of ordinary language, and if so, how this was to serve the practical interests of science, remains conjectural. But there can be no conjecture about what is to be accomplished by an empiricist language as regards metaphysics and theology. Metaphysics and theology are to be eliminated, and their terminology is to be kept out of the scientist's language. In this respect the positivist's aim in constructing a language is clear. And if this is the governing consideration, then to assess the positivists' attempts to provide a criterion of literal significance requires determining whether the various criteria, from verifiability to translatability into an empiricist language, have not been rigged to secure the desired end. It seems to me quite clear that these criteria all beg the question concerning the meaningfulness of terms and sentences, that they state, not what the conditions of meaningfulness actually are but what they are by decree. The conclusion that metaphysical statements are meaningless rests on tailored criteria; it commits a petitio principii.

11 Language, Truth and Logic, p. 67. 
That positivists have made a show of demonstrating the impossibility of metaphysics while assuming it in the criteria for meaningfulness will 1 think appear on examining these criteria. In presenting the empiricists position I have slurred over difficulties in the formulation of the various criteria of verifiability which should now be brought out. When, in their first formulation, they said a statement is meaningful if and only if it can be verified or falsified, the referent of the term "it" is ambiguous. In the sense of "statement" in which a statement is said to be meaningful or meaningless, the word "statement" means the same as "sentence". In the sense in which a statement is said to be verifiable or falsifiable, "statement" means the same as "pro. position". And "sentence" and "proposition" do not mean the same. As Moore points out in his Commonplace Book, "Every proposition which is true, except propositions about sentences, could have been true, even if there had been no sentences: from the fact that it is true that the sun is shin. ing it doesn't follow that there are any sentences." "Sentence" and "proposition" are not interchangeable terms, as indicated by the fact that a sentence may sensibly be said to be meaningful, or written in red ink, but cannot sensibly be said to be verified or to be true, or to be deducible from another sentence. As Moore said, "To talk of deducing one sentence from another is not English." We might, then, reframe the criterion so as to conform to English usage as follows: A declarative sentence which does not express an a priori proposition is meaningful if and only if the proposition it expresses can be verified or falsified in senseexperience. But the criterion so formulated involves a contradiction: A sentence cannot express a proposition, of whatever kind, and at the same time be meaningless. To say a sentence expressing a proposition is meaningless because it expresses an unverifiable proposition therefore will not do. However, the criterion can be so formulated as to avoid

12 P, 375.

13 lbid, p. 258. 
this objection, viz: A sentence which does not express an analytic proposition is meaningful if and only if it express a proposition verifiable in sense-experience. But then a fresh objection arises, namely, that it is tailored so as to throw out as meaningless any sentence failing to express a proposition open to sense test. It does succeed in eliminating such sentences as "A transcendent God exists" and "There are abstract objects, denoted by numerals, which are apprehended only in thought". But it does so only by linguistic fiat, and can hardly be expected to influence the metaphysician and the theologian. Nor should it have influenced the positivist. One can imagine a traditional metaphysician pointing out that one might as well condemn a sentence as meaningless because it does not express a proposition verifiable visually, or that he could lay down the equally arbitrary stipulation that a sentence be meaningful only if it expresses a proposition open to supersensible verification. Certainly a metaphysician like Bradley, who wrote, "... we seem to touch and have communion with what is beyond the visible world" $"$ would object to a criterion tailored with an eye to eliminating this sentence as meaningless.

In the assessment I have just made of the various formulations of the verifiability principle I have drawn from M. Lazerowitz' study of them in his book The Structure of Metaphysics. ${ }^{15} \mathrm{I}$ think it is clear that the same objection, of begging the question, applies to the criterion which makes the meaningfulness of a sentence depend on its translatability into an empiricist language. Quite evidently the language is constructed to prevent the formation of all metaphysical sentences. It is a curious historical fact that Kant eliminated the possibility of metaphysics by committing a similar petitio. He said: "Now all our intuitions are sensible; and this knowledge, insofar as its object is given, is empirical... Consequently there can be no a priori know-

14 Appearance and Reality, p. 5.

15 Pp. 49.57. 
ledge, except of objects of possible experience... Only our sensible and empirical intuition can give to [the concepts of the understanding] body and meaning." tes the possibility of knowledge of anything beyond the bounds of sensible experience in a way that would hardly impress Bradley or Plato.

The program of logical empiricism in relation to theology, metaphysics, and science can now be summed up. The theologian who is dissatisfied with naive folk-doctrines about God makes his escape from the scientific criticism that his beliefs are superstition by taking refuge in metaphysics, where he can hide his belief in a cosmic greybeard under the notion of a transcendent God. Logical positivists block this escape by declaring his metaphysical statement nonsensical; and there is no return for him to doctrines about a being whose existence and properties are subject to scientific tests. For by such tests these doctrines could be shown with the greatest probability to be false. But if the positivists' criterion of meaningfulness cannot be used to demonstrate that metaphysical statements are nonsense, do we simply return to the status quo ante? To this question I think the answer is No. For one thing, we cannot assume that these statements are meaningful merely because they have not been shown meaningless. For another, what the logical empiricists have done is to give us a new way of conceiving the nature of metaphysical positions. When Kant talked of empty concepts, and Hume of fictitious ideas, they were suggesting, in a semi-psychological idiom, that metaphysical positions constituted a peculiar sub-class of theories. Logical empiricists have given us that idea that we need new spectacles. Through them we could look at the language by which a theory purports to be expressed, and metaphysical problems and the problem about the nature of metaphysics might be seen as linguistic problems. Our attention needs to shift from apparent questions of ontology

${ }^{10}$ The Critique of Pure Reason, trans, by N, K. Smith, pp. 173-74, 163. 
to questions of language. Moore has remarked how curious it is that "language... should have grown up just as if it were expressly designed to mislead philosophers". ${ }^{17}$ And Wittgenstein has remarked on "the bewitchment of our intelligence by means of language",,$"$ in consequence of which we hope for an answer to a philosophical question in the same way we hope for an answer to a scientific ques. tion. If either remark is justified then the shift of attention to language, which positivist practice effects, gives hope of unmasking what a failure to attend to language obscures. Sentences of metaphysics may not turn out to be nonsense, but their function must be quite different from what it has been traditionally conceived to be: to convey information about the world, or to record the analysis of a concept.

17 Philosophical Studies, p. 217.

18 Philosophical Intestigations, p. 47. 


\section{RESUMEN}

En el empirismo lógico se encontraban intimamente conectados dos programas: la eliminación de la metafísica y la unificación de las ciencias mediante la formulación de un lenguaje en el cual se expresara todo lo inteligible. La eliminación de la metafísica significaba, en efecto, desterrar del lenguaje de la ciencia las oraciones no sig. nificativas y esto requería tener una idea de lo que idealmente sería el lenguaje científico.

Wittgenstein suministró una caracterización del significado que permitía distinguir entre el significado de dos clases de enunciados: los enunciados a priori, como los de la lógica, que no pueden ser confirmados ni refutados empiricamente, pero que "nada dicen", es decir, que no procuran información fáctica, y los enunciados em. píricos, con contenido fáctico, cuyo significado es su método de verificación. Los positivistas establecieron por criterio que un enunciado no-a priori es significativo si y sólo si puede ser verificado o falsificado en la experiencia sensible. Los enunciados metafísicos parecían confundir ambas clases de enunciados: parecian afirmar algo fáctico y, a la vez, pretendian demostrarse sin hacer uso de la obser. vación. Los positivistas sostuvieron que esos enunciados eran "en principio" inverificables.

Algunas dificultades obligaron a ampliar el criterio de significatividad asi: un enunciado no-a priori es significativo si es capaz, en principio, de ser confirmado, es decir, si puede describirse una evidencia que lo haga probable. Los enunciados metafisicos tampoco en este sentido más amplio aparecen como significativos. Pero podria sostenerse que para saber que un enunciado sea probable es menes. ter saber cuando podria verificarse concluyentemente; la posibilidad de describir una evidencia que verifique un enunciado como probable descansaria en la evidencia que lo verificara concluyentemente.

Popper trató de responder a la dificultad de una verificación concluyente para los enumciados universales, con un nuevo criterio: un enunciado es significativo si es falsificable en teoría. Pero según este criterio resultarian sin sentido enunciados existenciales como "existen unicornios", en cambio la negación de este enunciado sería significativa. Por otra parte, cualquier conjunción de una oración, significativa o no, con una oración significativa sería también significativa.

Para evitar estas dificultades, Ayer propuso otro criterio: S es significativa si, en conjunción con hipótesis subsidiarias arroja enunciados de observación no derivables sólo de las hipótesis subsidia- 
rias. Por desgracia, este criterio permitiria considerar también como significativas proposiciones metafisicas.

La consecuencia de estas reformulaciones fue renunciar a especificar la significación de un enunciado en términos de su relación con enunciados de observación. Entonces se pensó en la construcción de un lenguaje libre de terminología metafísica, que podriamos llamar "lenguaje empírico". Puede formularse un nuevo criterio de significatividad: un enunciado no-a priori tiene contenido cognoscitivo si puede traducirse a un enunciado formulable en un lenguaje empirico. Es menester, pues, construir un lenguaje al cual puedan traducirse todos los enunciados del lenguaje natural susceptibles de ser puestos a prueba por los métodos de la ciencia; este lenguaje estaria libre de terminologia metafísica. Aquí se hace patente la conexión entre los dos programas del positivismo: la eliminación de la metafísica y la unificación de la ciencia.

La sintaxis de ese lenguaje son las reglas de formación contenidas en un sistema lógico como Principia Mathematica. El vocabulario no lógico regulado por ellas debería consistir en términos observacionales. Mientras en los comienzos de esta doctrina los términos observacionales designaban aparentemente "lo dado", en un sentido fenomenalista, después se consideró que denotaban características observables de objetos físicos, tomándolos asi como "términos de cosas". Estos dos tipos de lenguaje ofrecen una alternativa.

Al tratar de conectar, mediante inferencias, los enunciados de experiencia con esos enunciados del "lenguaje empírico", constituidos por términos observacionales, surgen dificultades. El problema de esta traducción varía según que los términos observacionales desig. nen cualidades sensoriales o caracteristicas de cosas. En el primer caso, el problema está en reducir enunciados sobre cosas a enunciados sobre datos sensoriales, en el segundo, en traducir enunciados de experiencia a enunciados sobre estados físicos o corporales. La elección del primer miembro de la alternativa parece conducir al solip. sismo, la del segundo, a una forma de materialismo filosófico; y resulta irónico que los positivistas tengan, asi. que rechazar el cargo de asumir esas posiciones metafisicas inverificables.

Cualquer "lenguaje empirico" tiene el propósito de permitir la traducción de los enunciados cientificos a enunciados que sólo contengan términos observacionales. Pero no todos los términos de enunciados científicos son traducibles a términos observacionales por simple definición. Tres clases de términos presentan dificultades: términos disposicionales, como "magnético", términos métricos, como "longitud", y términos teóricos, como "electrón". En cada uno de estos casos, el programa reduccionista tropieza con graves problemas.

Por otra parte, se ha criticado al positivismo que su propia po. 
sición es metafísica, pues implica un materialismo metafísico. Podría preguntarse si el positivismo no trasfiere simplemente la alternativa materialismo-idealismo a un nivel lingüistico. La tesis de que el lenguaje físico es universal y de que todos los enunciados, para poder ser significativos, deben poder reducirse a él, implica considerar cuantitativamente determinables todas las situaciones objetivas y todos los objetos. En particular, todos los enunciados de evidencia sensibles deben poder reducirse a términos físicos; lo que es una propuesta de una forma de materialismo. Pero es un materialismo establecido por un fiat, $\sin$ dar un argumento que muestre la equiva. lencia de un enunciado de experiencia y uno sobre estados corporales.

Si, en cambio, el "lenguaje empírico" se considera constituido por enunciados que contienen términos de datos sensoriales, se plantea el problema de reducir los enunciados de un lenguaje físico a enun. ciados protocolarios sobre sensaciones, evitando, al mismo tiempo, el solipsismo. En efecto, cada enunciado protocolario se referiría, entonces, a sensaciones propias del observador y no podría verificar un enunciado de la física. Carnap sostuvo que estas dificultades des. aparecerán si nos restringimos al modo formal de hablar. Posiblemente pensaba en la posibilidad de encontrar un nexo entre las oraciones del lenguaje físico y las del protocolario. Este nexo fue establecido por Ayer: los enunciados sobre cosas materiales pueden traducirse a enunciados implicativos sobre contenidos sensoriales. "X es una mesa", por ejemplo, significa "si se cumplen ciertas condiciones específicas, entonces ocurrirá una experiencia sensible".

A esta tesis pueden hacerse dos criticas, En primer lugar, el fenomenalismo a que conduce es simplemente otra postura filosófica en la que es dificil escapar del idealismo. Neurath y Carnap fueron en esa dirección al proponer una teoria de la verdad como coherencia. Los enunciados sobre cosas no podian ser comparados con objetos sino entre si. Por otra parte, Schlick notó que ningún enunciado sobre cosas puede ser verificado concluyentemente, pues nin. gún número finito de enunciados de experiencia implicará un enunciado sobre cosas; en otras palabras: el análisis de un enunciado sobre cosas arrojaría una conjunción infinita de enunciados de experiencia. Bajo estas cuestiones está el problema del solipsismo: ¿Qué nexo puede haber entre enunciados indudables de la experien. cia privada y los enunciados dudables sobre cosas? Una segunda crítica es que nunca se ha efectuado una reducción de un enunciado sobre cosas a series de enunciados implicativos sobre conteni. dos sensoriales. Parece pues que, si se toma como lenguaje básico un lenguaje fenomenalista, fracasa el programa de encontrar un len. guaje común a todas las ciencias. 
Los propósitos que debia cumplir ese lenguaje nunca fueron del todo claros, salvo en un aspecto: la eliminación de la metafísica y la teología y la expulsión de su terminología del lenguaje cientifico. Habria, pues, que determinar si los diferentes criterios de significatividad propuestos alcanzaron ese fin. Parece que caen al lado de la cuestión, pues no establecen cuáles son las condiciones de significatividad efectivas, sino cuáles han de ser por decreto. La conclu. sión de que los enunciados metafísicos carecen de sentido comete, asi, una petitio principii.

Cuando los positivistas establecieron primero que un enunciado es significativo si y sólo si puede ser verificado o falsificado, el sentido de "enunciado" era ambiguo. En el sentido en que se dice de él que es "significativo" o "sin sentido" significa lo mismo que "oracion"; en el sentido en que se dice "verificable" o "falsificable" significa lo mismo que "proposición". Puede decirse de una "oración" que es significativa, pero no que sea verdadera o deducible de otra. Podria reformularse el criterio asi: una oración declarativa que no expresa una proposición a priori es significativa si y sólo si la proposición que expresa puede ser verificada o falsificada en la experiencia sensible. Pero este criterio envuelve una contradicción: una oración no puede expresar una proposición y a la vez carecer de sentido. Si tratamos de evitar esta objeción surge otra: que el criterio de significatividad es forjado expresamente para descartar eualquier oración que no exprese una proposición susceptible de ser probada por los sentidos. Sólo elimina esas oraciones por un fiat lingüistico. La misma objeción se aplica al criterio que hace depender la significatividad de una oración de su traducción a un "len. guaje empirico". Evidentemente ese lenguaje ha sido construido para evitar la formación de oraciones metafisicas.

Si el criterio de significatividad positivista no puede usarse para demostrar que los enunciados metafísicos carecen de sentido, ¿debemos retornar a la situación anterior? No. Por una parte, no se puede asumir que los enunciados metafísicos son significativos sólo porque no se ha mostrado su sin sentido. Por otra, los empiristas lógicos nos suministraron una nueva manera de concebir la naturaleza de las posiciones metafisicas. Los problemas metafísicos pueden verse como problemas lingüisticos. Debemos volver nuestra atención de aparentes cuestiones de ontologia a cuestiones sobre el lenguaje. Este cambio de la atención, efectuado por la práctica positivista. da una esperanza de desenmascarar las confusiones producidas por el lenguaje. Las oraciones de la metafisica tal vez no carezcan de sentido, pero su función debe ser enteramente distinta a la que se les adjudicó tradicionalmente: suministrar información sobre el mundo o expresar el análisis de un concepto. 